"Do You Ring? Or Are You Rung For?": Mass Media, Class, and Social Aspiration in Edwardian Ireland

Author(s): Stephanie Rains

Source: New Hibernia Review / Iris Éireannach Nua, Vol. 18, No. 4 (GEIMHREADH / WINTER 2014), pp. 17-35

Published by: University of St. Thomas (Center for Irish Studies)

Stable URL: https://www.jstor.org/stable/24625154

Accessed: 16-08-2019 11:42 UTC

JSTOR is a not-for-profit service that helps scholars, researchers, and students discover, use, and build upon a wide range of content in a trusted digital archive. We use information technology and tools to increase productivity and facilitate new forms of scholarship. For more information about JSTOR, please contact support@jstor.org.

Your use of the JSTOR archive indicates your acceptance of the Terms \& Conditions of Use, available at https://about.jstor.org/terms

University of St. Thomas (Center for Irish Studies) is collaborating with JSTOR to digitize, preserve and extend access to New Hibernia Review / Iris Eireannach Nua 


\section{Stephanie Rains}

\section{"Do You Ring? Or Are You Rung For?": Mass Media, Class, and Social Aspiration in Edwardian Ireland}

In October 1903, readers of Ireland's Own might have noticed, among the more conventional advertisements for soap and baby food, an announcement of the Dr. McLaughlin Company's Electro-Vigour belt, which promised to "pour glowing, exhilarating vitality into you while you sleep; it rejuvenates, animates sluggish circulation, stimulates the brain into activity and fills the body with life, ambition and endurance."

This advertisement was not unusual in popular publications of the early twentieth century. It and many others played upon a very particular set of anxieties about masculinity, class, and the experience of mass culture. The fact that these fears are evident in popular media is not a coincidence: this was the era of an exponentially growing mass media, accompanied by great anxieties about what it might mean to be part of a mass audience. Scholars have been slow to see that experience in Ireland, probably due to a traditional reluctance to recognize Irish modernity, including its experience of mass culture. Because nationalism and national identity were so central to Irish public discourse of the period, there has been a much greater critical emphasis upon the experience of being a member of a "national public" than upon the experience of being a member of a "mass audience." Ireland's status as a small nation-in which that national public is presumed not be a faceless crowd-may also have contributed to this lack of discussion of mass audiences.

But mass culture depends less upon sheer numbers than it does upon a conception of its audience as a mass, and therefore as a market to be segmented for the consumption of particular products. Ireland in the early twentieth century was actually a highly developed mass media market. It not only had a popular publishing industry of its own by this point; it was also experiencing the widespread circulation of imported newspapers, magazines, advertisements, as well as the products they sold. This was an experience of international mass culture

1. Electro-Vigour advertisement, Ireland's Own, October 14, 1903, p. 21.

NEW HIBERNIA REVIEW / IRIS ÉIREANNACH NUA, 18:4 (GEIMHREADH / WINTER, 2014), 17-35 
on a greater scale than that of many other countries, and one that undoubtedly involved the creation of an Irish mass market.

Ireland's Own was a story paper established in Wexford in 1902 by John M. Walsh, who had inherited the People Printing Works from his father and also owned several local newspapers. Within a couple of years of starting Ireland's Own, Walsh moved the magazine to Dublin, where he founded the Dublin Saturday Post. ${ }^{2}$ Although there are no reliable circulation figures, Ireland's Own (which cost $1 \mathrm{~d}$ a week) was almost certainly the most popular Irish story paper during the early twentieth century, perhaps selling as many as 80,000 copies per week. ${ }^{3}$

Story papers, as their name suggests, were weekly papers focused upon short and serial fiction (mainly adventure and romance stories), along with regular columns, competitions, and feature articles. They were designed to appeal mainly to younger male readers, aged approximately fourteen to twenty-four, especially those of the upper working- and lower middle-classes, but a variety of evidence from the magazines themselves suggests that they were often read by entire families. The more successful of the British story papers, such as the Boys' Own Paper and Magnet, ranked among the most widely read publications of the era, and were, of course, available in Ireland, as were most British papers and magazines. American equivalents, mainly published in New York, included Argosy and the All-Story Paper, both produced by the publishing magnate Frank Munsey. ${ }^{4}$ Like the other Irish story papers, such as the Irish Emerald, the Shamrock and the Irish Packet, Ireland's Own attempted to cope with the competition from high-circulation British imports by emphasizing their Irishness and also by claiming to be more "wholesome."

This claim had particular potency during the early twentieth century, in the context of the "social purity" movement, which campaigned against fiction and other popular forms that it perceived to be debauched and immoral. The social purity movement was particularly active in Ireland in 1911 to 1913 , although it focused its energies upon British publications. ${ }^{5}$ The sorts of products that Oliver St. John Gogarty described in 1906 as "hideous advertisements of patent ways of recovering from indulgence" were a major target of the anti-vice campaigns; it is particularly striking, then, that a supposedly "wholesome" publication such as Ireland's Own should have been advertising products like the Electro-Vigour

2. Biographical dictionary entry in Scoop! The People Behind the News, http://www.scoop -database.com/.

3. Robert Brennan, Allegiance (Dublin: Brown and Nolan Press, 1950), p. 25.

4. See: Kelly Boyd, Manliness and the Boys' Story Paper in Britain: A Cultural History, 1855-1940 (Basingstoke: Palgrave Macmillan, 2003); Helen A. Fairlie, Revaluing British Boys' Story Papers, 19181939 (Basingstoke: Palgrave Macmillan, 2014).

5. Stephanie Rains, “'Nauseous Tides of Seductive Debauchery': Irish Story Papers and the AntiVice Campaigns of the Early Twentieth Century," Irish University Review (forthcoming). 


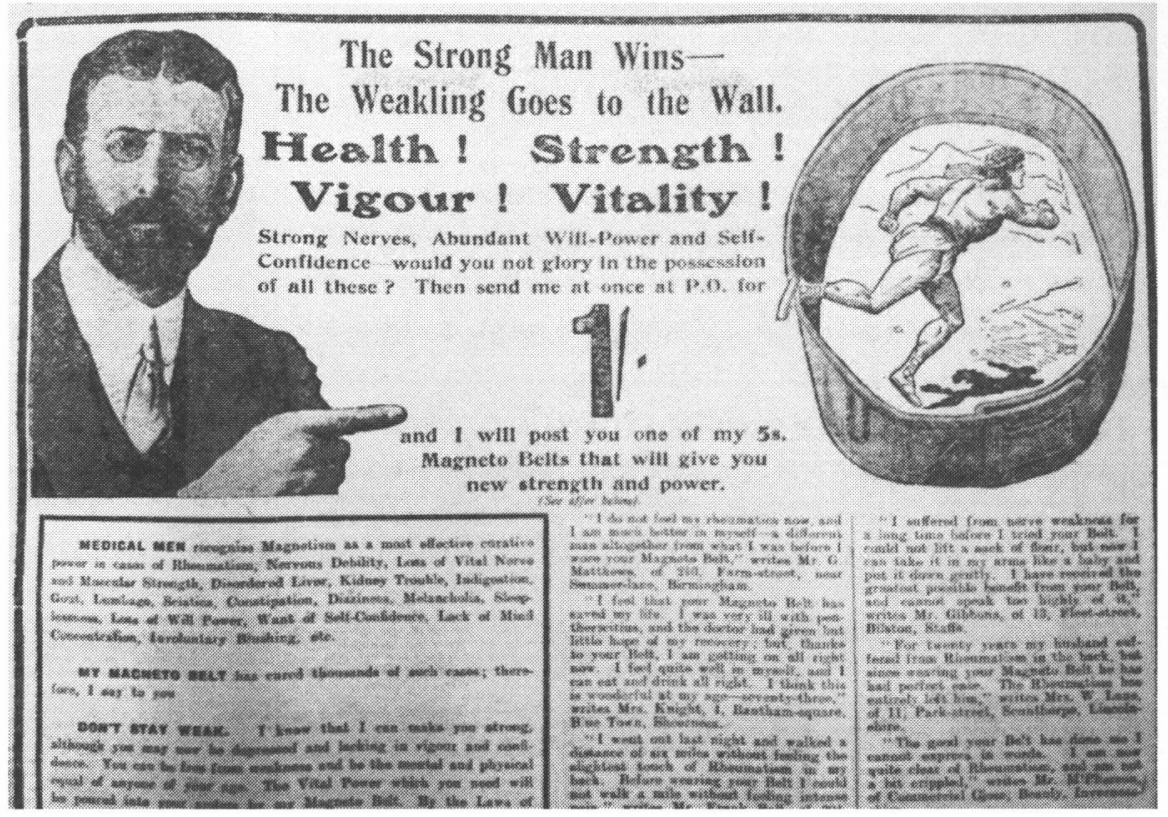

Advertising for Ambrose Wilson's Magneto Belt, published in Ireland's Own in July 1912. Image courtesy of the National Library of Ireland.

Belt-which was using terminology in its advertisements clearly intended to imply that it would cure the supposed after-effects of youthful masturbation. ${ }^{6}$

Within a few years of the advertisement for the Electro-Vigour Belt, many other such products were being advertised in Ireland's Own, and it is noticeable how many of them also laid stress upon the concepts of vigor, vitality, and the "vital forces" of various kinds that readers could expect to acquire after using them. These ranged from other electric belts, such as the Ajax Dry-Cell which was to be worn in bed, when wearers would "feel the gentle glow of vital warmth flowing through your body," to Bernarr A. MacFadden's book The Virile Powers of Superb Manhood; How Developed, How Lost: How Regained, which was advertised on a more or less weekly basis during 1906 as an aid to regaining "lost vigour and vitality." By 1912, the volume of such advertisements had considerably increased. There were regular advertisements for such products as Professor Spencer Munro's Spinal Vitalizer, Frank R. Hartley's book How Failure Becomes Impossible - which posed the question "are you getting on as well, and as rapidly,

6. Oliver St. John Gogarty, "Ugly England I," Sinn Fein, September 15, 1906, p. 3. 
and as universally as you would like to?"-and Damaroid Tablets, which promised "manly strength" to those who became "Damaroid Men."

The most heavily advertised product, however, was Mr Ambrose Wilson's Magneto Belt of Life, soon joined by its female equivalent, the Magneto Corset. One of a variety of dramatically illustrated advertisements for the Magneto Belt claimed "The Strong Man Wins-The Weakling Goes to the Wall"; another promised that once the Magneto Belt had been donned, "You face each day with Courage. The Haunting Sense of Failure, the Shadow of Defeat, the Dread of Failure no longer dogs you day by day." 8

Other advertisements focused on a different kind of "magnetism." Numerous books and pamphlets offering to improve readers' powers of personal attraction or even direct power over others were advertised in Ireland's Own, and like the appliances claiming to use either electricity or magnets to boost vigor and vitality, these became more heavily advertised in 1912. In April 1912, a Mr. Slade-described as The Human Magnet-advertised his "system," which he assured readers would allow them to develop the "attractive force." Slade explained that "every human being possesses this subtle power, dormant though it may be-it is only the development of this gift that distinguishes Success from Failure in all phases of Life." The precise nature of this "system" was not delineated, but interested readers were invited to send a stamped, addressed envelope and three penny stamps to a London address in order to learn more. ${ }^{9}$ Three months later, a Mr. Spencer Wallis, whose "remarkable course on Personal Magnetism is creating a deep impression in thinking circles" was offering to forego his usual fee of one guinea for both a consultation and a copy of his book Scientific Elimination of Failure for those readers who responded within ten days of the advertisement appearing. Shortly afterward, the self-styled National Institute of Sciences in London was distributing a book called The Key to the Development of the Inner Forces by one Professor Knowles, a "famous Hypnotist" who would reveal "How Prominent People Have Gained Wealth and Popularity." Knowles had developed a method that "Enables Anyone to Control Thoughts and Acts of Others." ${ }^{10}$ Before the end of that year, in November 1912, an organization called the London Institute of Menti Culture was distributing Hartley's How Failure

7. Ajax Dry-Cell advertisement, Ireland's Own, April 11, 1906, p. 23; Bernarr A. MacFadden, The Virile Powers of Superb Manhood; How Developed, How Lost: How Regained (New York: Physical Culture Publishing, 1900); Munro's Spinal Vitalizer advertisement, Ireland's Own, May 22, 1912, p. 9; Frank R. Hartley, How Failure Becomes Impossible (publishing details unknown); Damaroid advertisement, Ireland's Own, September 4, 1912, p. 20.

8. Magneto Belt of Life advertisement, Ireland's Own, December 6, 1911, p. 27.

9. Human Magnet advertisement, Ireland's Own, April 24, 1912, p. 7.

10. Spencer Wallis, Scientific Elimination of Failure (publishing details unknown), advertised in Ireland's Own, June 12, 1912, p. 12. 


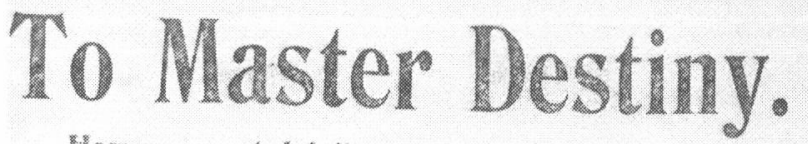

How unsuspected inlluences decide the frite of Mar. Startling results by a few days' application of a new, casy Success-System, now revealed for the first timc.

\section{I,000 GUINEAS GUARANTEE.}

"Ireland's Own" Readers nust write at once for Free Explanations, Free Lessous, and Free Copy of the Most Starting Book Ever Published.

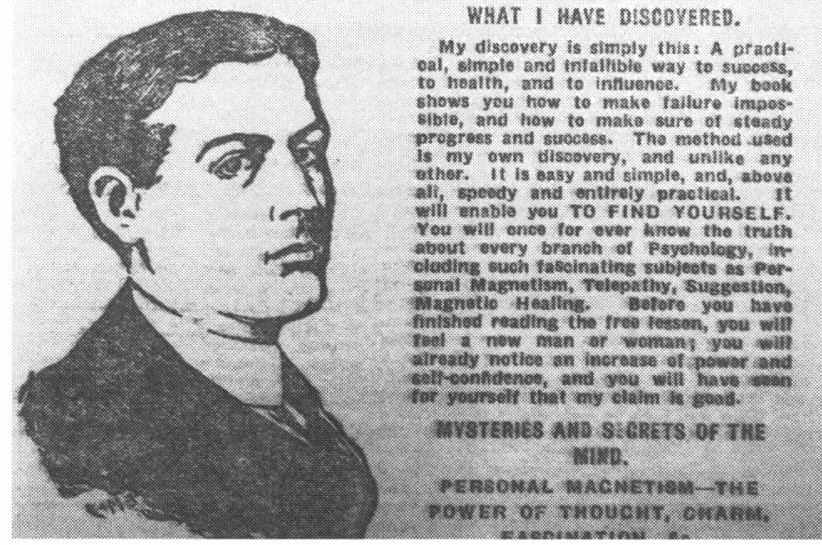

Advertisement of How Failure Becomes Impossible published in Ireland's Own in November 1912. Image courtesy of the National Library of Ireland.

Becomes Impossible, promising that it would explain, "How unsuspected influences decide the fate of Man," and teach readers to "Master Destiny" and make "failure impossible" by the application of the author's system of "Personal Magnetism, Telepathy, Suggestion [and] Magnetic Healing." 1

The following summer, the first of a long-running series of advertisements for the "Magnetic Girl" appeared. These offered to explain "How She Compels Others to Obey Her Will," and were another way of advertising Professor Knowles's book The Key to the Development of the Inner Forces. ${ }^{12}$ The advertisements featured a small photograph of a young woman, with a captioned that read "Miss Josephine Davis, the popular stage favourite ... declares that Professor Knowles'

11. Elmer Knowles, The Key to the Development of the Inner Forces (publishing details unknown), advertised in Ireland's Own, July 10, 1912, p. 12, and advertisement for the British Institute of Menti Culture, November 27, 1912, p. 9.

12. "Magnetic Girl" advertisement in Ireland's Own, June 3, 1914, p. 16. 
book opens the door to success, health, and happiness to every mortal." As was frequently the style of such advertisements, the book was being offered free in return for two penny stamps to cover postage. ${ }^{13}$

The advent of war did not end the supply of such advertisements. Not only did the Magneto Belt and Magneto Corset, along with the "Magnetic Girl," continue to advertise after the outbreak of war, but by 1915 two new books (both by Mr. Norman Barclay, "London's foremost Psychologist") were being advertised, one of which was titled Revelations of a Mysterious Force or, The Power That Rules the World. Barclay made especially wide-ranging claims for the knowledge his books would impart, referring not only to the then-illegal practices of palmistry and fortune-telling, but also promising to reveal "the secret of Personal Magnetism ... and ... how anyone can harness and direct a subtle, unseen force which controls the thoughts and actions of others." 14

What the electric or magnetic belts and the books on personal magnetism had in common was a sense that the universe, the human body, and the mind were governed by powerful but invisible forces, which - if they could only be harnessed-would allow individuals to master their own fates and perhaps those of others too. Along with a belief in the possibilities of "mysterious forces" waiting to be harnessed, a common element in the advertisements for both electrical appliances and treatises on personal magnetism was their emphasis upon the lauding of strength and individual will, as well as a fear of weakness and failure. This aspect was something they had in common with the advertising for other products. At the same time as readers were being assured that they could "scientifically" eliminate failure or master their destiny by using magnetism of some kind, they were also being invited to guarantee personal success in other, more conventional ways.

Many advertisements for self-improvement through education and training appeared in Irish publications in the early twentieth century, and indeed, in some weekly magazines entire columns were devoted to the topic, which was also the subject of frequent feature articles. However, there were also commercial advertisements that were rather less sober in their exhortations to personal advancement. The International Correspondence Schools (based in London), for example, ran advertisements showing a well-dressed man sitting at a large desk and pressing a bell on the wall next to him; above this drawing was the advertisement's headline, "Do you Ring? Or are you rung for?" 15 Their com-

13. The use of the term "Magnetic Girl" was almost certainly a reference to the Richard Marsh novel of the same name, published in 1903. Richard Marsh, The Magnetic Girl (London: John Long, 1903). 14. Norman Barclay, Revelations of a Mysterious Force or, The Power That Rules the World (publishing details unknown), advertised in Ireland's Own, August 18, 1915, p. 5.

15. International Correspondence Schools advertisement, Ireland's Own, August 5, 1914, p. 5. 
petitors, Holborn Hall College (also of London), advertised using a drawing of an even better-dressed man, wearing a frock coat and literally leaping over the Houses of Parliament, with the headline, "Your Future Depends on Yourself! Be a Private Secretary (Not a 30 a week man)." ${ }^{\prime 6}$ Less than a month after the outbreak of World War I, the International Correspondence School was running an advertisement that assured readers that "The Trained Man Wins in War and Peace." 17

By the early twentieth century, many such commercial colleges and correspondence schools were operating in Britain and Ireland, most of them targeting clerical workers and those who aspired to join the clerical ranks. Evening, part-time, and correspondence qualifications in accounting, bookkeeping, shorthand, and business French, as well as some more technical training in several branches of engineering, were offered to those seeking to enter or progress in clerical work. Although London, as the metropolitan heartland of the British empire's financial, business, and professional activities, was the location for many such businesses, others were based in "provincial" cities. These included the All-Ireland Correspondence College based on Lower Abbey Street in Dublin, and the National Examining Institute of Ireland, which was on Grantham Street. ${ }^{18}$ The rise of these correspondence schools was an indication of the extent to which clerical careers had become an ambition for ordinary young men - and increasingly, young women as well-across all of Britain and Ireland.

At the time, only a tiny percentage even of boys (let alone girls) remained in school beyond primary level, though free education up until that age was well-established, albeit availed of in decreasing proportion according to the children's socioeconomic background. But in broad terms, by 1912 everyone in Ireland aged twenty or younger had theoretically benefitted from free and compulsory education up until at least the age of eleven, and in some cases fourteen. In reality, of course, attendance at school by. working-class Irish children was low, especially after the age of thirteen. Nevertheless, by 190186 percent of the Irish population was deemed literate; this percentage would have been higher among younger age groups. ${ }^{19}$ One effect of a rapid increase in levels of literacy

16. Holborn Hall College advertisement, Ireland's Own, March 24, 1915, p. 17.

17. International Correspondence Schools advertisement, Ireland's Own, September 2, 1914, p. 12.

18. The National Examining Institute of Ireland on Grantham Street was run by M. J. O'Mullane MA, who was also heavily involved with Our Boys magazine, a publication for adolescent boys begun in 1914 by the Christian Brothers and intended to provide a Catholic, Irish alternative to the British Boys Own Paper. O'Mullane wrote school stories for the paper and may even have edited it during its early years.

19. Clare Hutton, "Publishing the Irish Cultural Revival, 1891-1922" in The Oxford History of the Irish Book, volume V: The Irish Book in English 1891-2000 (Oxford: Oxford University Press, 2011), p. 19. 
and other general education was a concomitant rise in employment and status aspirations-especially from those young people from the upper-working class and lower-middle class, for whom the possibility of skilled, white-collar employment offered a significant change in status and opportunity.

This is not to suggest, however, that these aspirations were particularly practical for many boys and girls from these class backgrounds. The magnitude of a move into clerical employment-along with the difficulty of making it with no more than the average level of formal education-is perhaps the reason why such magazines as the Irish Emerald and the Shamrock (and after 1912, their merged entity, the Shamrock and Irish Emerald) chose to develop "Students' Page" features as long-running and central features of their format. Their readership included significant numbers of young men and women for whom clerical work was an ambitious choice, both in terms of the income it might offer, and also of the difficulty of passing its barriers to entry.

That difficulty is reflected in the tone, content, and factual information communicated through the columns themselves. The consistency of their advice regarding writing style, grammar, and punctuation over the years does suggest that many of their young readers were stretching their educational attainments to the limit by aspiring to pass clerical entrance examinations. And yet, the columns obviously met a perceived need among readers: they ran every week for many years. The extent to which they actually assisted readers to pass clerical entrance examinations is impossible to gauge, but they were undoubtedly responding to, encouraging, and reinforcing a significant ambition among working-class or lower middle-class school-leavers for a job with "prospects" and the social and economic status that came with clerical work.

In the early twentieth century, a typical adult man's unskilled or manual laboring wage was approximately $\mathfrak{k}_{50}$ a year. As a result, even the second division clerkships, available to boys as young as seventeen, carried a financial appeal. The starting salary for such a position in 1900 was $\mathfrak{E} 70$, but could potentially rise to $\mathfrak{E} 350$ over the years; a very good middle-class income, however few might actually achieve it. ${ }^{20} \mathrm{~A}$ similar grade of second-class clerkship in the Dublin Police Court paid $\mathfrak{E} 80$ a year starting salary, but with yearly increments of $\mathfrak{E}_{5}$ up to an upper limit of $\mathfrak{E}_{150}$; first-class clerks were paid $\mathfrak{E}_{180}$ a year rising by $\mathfrak{E}_{10}$ a year to $\mathfrak{E}_{300} .^{21}$ The general tone of the "Students' Pages" encouraged planning, sustained hard work, and delayed gratification for boys developing their careersall of which were, in themselves, middle-class behaviors and attitudes. They were also behaviors that do not always come naturally to adolescents, something perhaps recognized by W. Stewart Thompson's advice in the Irish Emerald to

20. "Students' Page," Shamrock, January 13, 1900, p. 237.

21. W. Stewart Thompson, “Our Students' Page," Irish Emerald, July 6, 1901, p. 439. 
school-leavers not to "think that the main object of life is mere pleasure, self-indulgence, amusement."22

At first glance, the sale of quack medical appliances and the careful preparation of sample essays for entrance examinations to respectable clerical jobs on the lowest rungs of the middle class would appear to be far removed from each other. What they shared in common however, was a deep concern-frequently and profitably stoked by the press and advertisers-about falling behind and being "weak" or undistinguished. We see the connection between ambitions for employment success and a desire for a more fundamental physical or psychological domination over others in the similarity of language of advertisements for electrical appliances, self-help books on personal magnetism, and training courses for career advancement. The Magneto Belt advertisements proclaimed that "The Strong Man Wins-The Weakling Goes to the Wall!", while Frank R. Hartley's How Failure Becomes Impossible declared that, "Get On or Get Out is the iron-rule of the world in business," and the Holborn Hall College insisted that "Your Future Depends on Yourself?" Across all of these advertisements, we find a fear of failure and an increasingly aggressive emphasis upon individual competitiveness, along with an individual's ability to separate themselves from the faceless crowd. In this respect, they were in tune with wider British and Irish culture, particularly with regard to fears of weakness.

The obsessive focus upon fears of weakness, degeneration, and loss of manhood in all corners of early twentieth-century Britain is well-known, and was marked notably by the establishment of the Interdepartmental Committee on Physical Deterioration in 1903 in the aftermath of the Boer War, but also by the establishment of Lord Baden-Powell's Boy Scouts in 1909, and the success of such "self-help strongmen" as Eugen Sandow and Bernarr MacFadden..$^{23}$ It was the urban working and lower-middle-classes whose apparent unfitness for imperial war prompted these concerns; and of those, it is worth noting that clerical workers had made up one of the largest proportions of military volunteers for the war. ${ }^{24}$

For more elite social commentators, clerks as a group became emblematic of the new kind of mass culture rapidly emerging from a generation of compulsory universal education. Literate but not cultured, and apparently weak in both body and spirit from their office environments and inferior status, the figure of the clerk became an icon of lower-middle-class failings, in terms of intellectual, cul-

22. W Stewart Thompson, "Some Friendly Counsel for Boys and Girls Leaving School," Irish Emerald, July 6, 1901, p. 439.

23. R. Brandon Kershner, “The World's Strongest Man: Joyce or Sandow?", James Joyce Quarterly, 30-31, 4 (Summer-Fall, 1993), 667-93.

24. Richard Price, An Imperial War and the British Working Class: Working-Class Attitudes and Reactions to the Boer War, 1899-1902 (Abingdon: Routledge, 2013), p. 228. 
tural, and physical prowess. Transformed by their uniform of dark suits into apparently interchangeable cogs in an ever-growing bureaucratic and hierarchical office machine, they were frequently depicted as cringing to their superiors and bullying to their juniors. Physically damaged by hours, days, and years hunched over their desks and working in stale indoor environments, the stereotypical clerk was spectacled, narrow-shouldered and pigeon-chested; a confirmation of some of Edwardian Britain's worst fears about physical and moral degeneration. Culturally, their tastes were disparaged as vulgar, half-digested mimicries of the truly educated, and as the product of mass education or even worse, of auto-didacticism. As a group, they comprised an important audience for the explosion in popular print culture from the late nineteenth century; many of the weekly story papers and cheap books being produced in ever-increasing numbers were aimed precisely at a clerkly readership with a basic education, a taste for leisure reading, and the disposable income to buy cheap publications specializing in adventure and romance - the culture of distraction so successfully sold by the mass media.

Probably the best-known and most fully-developed English depiction of a clerk as an exemplar of weakness and inadequacy was that of Leonard Bast, the self-educated clerk in E. M. Forster's 1910 novel Howard's End, whose veneer of undigested acculturation is contrasted with the authentic cultural aristocracy of the Schlegiel sisters. Bast, we are told, "stood at the extreme verge of gentility. He was not in the abyss, but he could see it, and at times people whom he knew had dropped in, and counted no more ... he was inferior to most rich people, there is not the least doubt of it. He was not as courteous as the average rich man, nor as intelligent, nor as healthy, nor as lovable." ${ }^{25}$ In Howard's End, Bast is excoriated for attempting to acquire upper-middle-class cultural knowledge and tastes and, it is made very clear to readers, remains doomed to fail in this regard because of the limits determined by his class position.

As early as 1888 , the Irish novelist George Moore had declared that the "spectre of famine, of plague, of war, etc., are mild and gracious symbols compared with the menacing figure, Universal Education ... which has already eunuched the genius of the last five-and-twenty-years of the nineteenth century, and produced limitless abortion in that of future time." ${ }^{26}$ George Bernard Shaw, in his 1910 play Misalliance, created an emotionally and physically weak clerk who forces his way into the home of an upper-middle-class family he holds responsible for his failures in life, but-such is his miserable physical condition-he is overpowered by one of the women of the house. ${ }^{27}$ Shaw himself had worked

25. E.M Forster, Howard's End and A Room with a View (New York: Signet, 1986), p. 402.

26. George Moore, Confessions of a Young Man (London: William Heinemann, 1888), p. 143.

27. George Bernard Shaw, Misalliance (London: Duke of York's Theatre, 1910). 


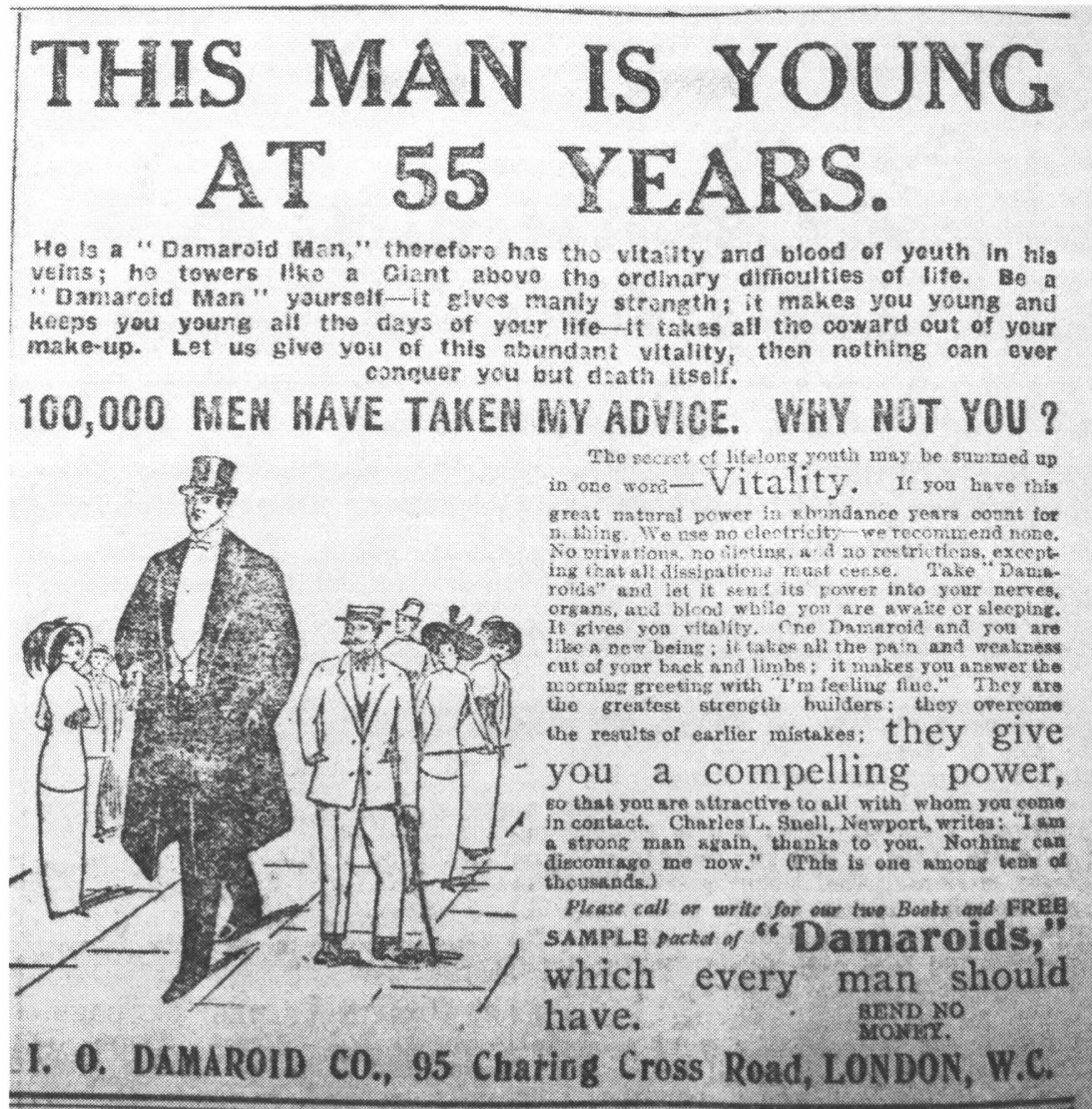

Advertisement for Damaroid Tablets, published in Ireland's Own in September 1912. Image courtesy of the National Library of Ireland.

as a junior clerk in Dublin after leaving school at the age of fifteen, before then moving to London, where he initially worked for Thomas Edison's nascent telephone business. ${ }^{28}$ Some of his professed beliefs suggest an affinity with the selfhelp books advertised in Ireland's Own - in particular, his belief in a natural "life force" in the universe that was directing the evolution of a "superman" (he wrote Man and Superman in 1903). W. B. Yeats's membership of the Hermetic Order of the Golden Dawn, which he joined in 1893, also reflected a belief in occult forces, which the initiated could direct toward personal development. In other words, the promises made by advertisements for magnetic belts or books on "personal

28. Nicholas Grene, "George Bernard Shaw," Dictionary of Irish Biography, ed. James McGuire and James Quinn (Cambridge: Cambridge University Press, 2009), www.ria.ie/Research/DIB/aspx. 
magnetism" belong to the same spectrum of beliefs and cultural concerns as those of Shaw and Yeats.

One of the key influences on both ends of this spectrum, it would seem, was Nietzche, and more specifically, his insistence upon the great struggle between the weak and the strong, along with a high degree of contempt for the condition of most ordinary individuals in modern society. If Shaw's Man and Superman owes a great deal to Nietzche's concept of the Übermensch, then so it would seem did the advertisements for magnetic belts and commercial training courses, however unintentionally. The art work that illustrated these advertisements (drawings of giant men towering over puny and faceless crowds, leaping tall buildings or "ringing" imperiously for their inferiors) drew strongly upon the popular Nietzchean discourse of strong men rising above-and ruling over-the weak masses. Clearly, concerns about the relations between weak and strong men, and a desire to be among the latter, was a widespread anxiety within Edwardian masculinity.

More general fears about Edwardian masculinity were manifest in the ongoing concerns about sexual purity and, in particular, the "masturbation panic" of the era, which was primarily concerned with the supposedly devastating moral and physical effects of male masturbation. ${ }^{29}$ This panic was a powerful social phenomenon in late-nineteenth and early-twentieth century England and Ireland, resulting in thousands of fear-mongering publications aimed at both boys and their parents, as well as public meetings and so-called "practical" innovations, such as English public school rules forbidding boys from putting their hands in their pockets. ${ }^{30}$

Quite aside from any moral concerns, anti-masturbation campaigners insisted upon direct physical consequences for the action, including life-long effects as a result of a youthful failure to overcome the masturbatory impulse. According to one pamphlet of 1912, masturbation was far from being a "secret sin"; instead it revealed itself to the world through "the pale, bloodless face, the sunken eyes, the soft, flabby flesh, the slovenly gait. ..." ${ }^{31}$ Even for those who escaped these conditions, a lifelong loss of "vitality" and betraying signs of weakness, such as dark circles under the eyes, were assured. The justification for a connection between masturbation and loss of "vigour" was, of course, the concept

29. Ironically, at the very same time female orgasms stimulated by doctors using early model electric vibrators were prescribed treatments for "hysteria." See Rachel P. Maines, The Technology of Orgasm: "Hysteria," the Vibrator, and Women's Sexual Satisfaction (Baltimore: Johns Hopkins University Press, 2001).

30. Alan Hunt, "The Great Masturbation Panic," Journal of the History of Sexuality, 8, 4 (April, 1998), 602.

31. F. Arthur Sibley (1912), cited in Katherine Mullin, James Joyce and Social Purity (Cambridge: Cambridge University Press, 2003), p. 99. 
of semen as a "life fluid," the loss of which would weaken and destroy the young man's constitution. As Alan Hunt describes the anti-masturbation campaigns of the era, "not only would the individual masturbator suffer, but the moral fabric of society is weakened, and the nation is deprived of virile young men who are the primary agents of both economic and military strength." ${ }^{32}$ It is within this context that the precise wording of advertisements for electrical and magnetic appliances for men would have been understood by an Edwardian readership: references to loss of vigor and strength, perhaps as a result of "youthful excess," would have been widely understood as referring to the supposedly lasting effects of masturbation. One of the best-known anti-masturbation books-which was often advertised in Ireland's Own-was The Virile Powers of Superb Manhood: How Developed, How Lost, How Regained, published by Bernarr A. MacFadden in 1900. The book decried the effects of sexual ignorance and advocated sexual education, but only within a strict moral framework of self-control; besides condemning masturbation, the book also advocated fresh air, exercise, teetotalism and abstinence from tobacco. In the preface, MacFadden explained that

the first duty of every male adult human is to be a man.... For if you are not a man, you are nothing but a nonentity! A cipher! And as long as you remain in this emasculated condition, your powers and capacities in every way will be bound by your weakened condition. ${ }^{33}$

In the first chapter, he went on to claim that, "Name any man famous in the world of literature, of art, or of science, and in nearly every instance he will be found to possess evidence of strong virility. The nervous energy, so necessary to the enormous labour which brought his success, was the same power that controlled his sexual instinct." ${ }^{34}$ Carolyn Thomas de la Peña, in her detailed account of the ways electricity was deployed for sexual effect at that time, argues that "if we consider impotence in the way it was defined by many of its sufferers-as a general loss of physical power-it makes sense to look to masturbation as a primary perceived cause." 35

The electric or magnetic belts claiming to rejuvenate and restore "lost vitality" were therefore appealing to readers' fears not just about the presumed sexual consequences of masturbation or other "youthful excesses," but also to fears of a wider loss of personal power and agency. In When Old Technologies Were New (1988), Carolyn Marvin notes of the quack electrical products of the era that,

32. Hunt, 595 .

33. Bernarr A. MacFadden, The Virile Powers of Superb Manhood; How Developed, How Lost: How Regained (New York: Physical Culture Publishing Co., 1900), pp. 5-6.

34. MacFadden, p. 12.

35. Carolyn Thomas de la Peña, "Designing the Electric Body: Sexuality, Masculinity and the Electric Belt in America, 1880-1920," Journal of Design History, 14, 4 (2001), 279-80. 
Virility, long associated with terms like force and energy, strength and vigor, which also described electrical properties, was an area ripe for electrical theorizing and therapeutic promise. A durable popular whimsy that the secret of eternal youth must be connected to electricity was transferred with special intensity to sexuality. The mysteries of both sex and electricity, deepened by ignorance of the physiology of one and the physics of the other, made these two natural allies in the hands of skilful ad men. ${ }^{36}$

Marvin's reference to "eternal youth" points to one of the undercurrents in these tangled Edwardian concerns about success, influence, and power: a fear of aging, and of the weakness that aging implied.

Further perusal of the advertising columns of newspapers and magazines reveals that two of the most frequently advertised products, by the early twentieth century, were hair dye and hair restorer, both products designed to disguise the effects of aging. These products dominated the advertising of both the up-market "society" papers and the "story papers" aimed at young working-class readers and their families. On one page in January 1902, Irish Society carried advertising for Eau Imperial, which dyed the hair and beard; Necroceine for covering gray hair; and "Erasmo The Queen of Hair Restorer." 37 The front wrapper of Ireland's Own in December 1911 carried advertisements for four different hair dyes offered by various pharmacies, two of which used the tag-lines "There Is No Need to Look Old" and "Don't Look Old." 38 The advertisement for Damaroid tablets, which proclaimed "This Man Is Young at 55 Years. He is a Damaroid Man," thus appeared within a broader landscape of products and marketing that fed upon fears of aging. ${ }^{39}$

The fears of imperial degeneration in the aftermath of the Boer War, fears of class degeneration in the aftermath of mass education, and fears of sexual degeneration in the aftermath of youthful masturbation all combined in the early twentieth century to make the figure of the young, lower-middle-class clerk (or aspirant clerk) in British life a figure of both loathing and of fear. Weak in body, spirit, and culture, he was presumed to be a pale shadow of both his peasant ancestors and his aristocratic betters. He was, however, one of an apparently ever-growing mass, whose numbers and forms of cultural expression were also mushrooming.

As a part of the Union in political and economic terms, and more incontrovertibly, as part of the market for British mass media and other popular cultural

36. Carolyn Marvin, When Old Technologies Were New: Thinking About Electric Communication in the Late Nineteenth Century (Oxford: Oxford University Press, 1988) p. 131.

37. Irish Society, 11 January 1902, p. 3275.

38. Ireland's Own, 13 December 1911, front wrapper.

39. Ireland's Own, 4 September 1912, p. 20. 


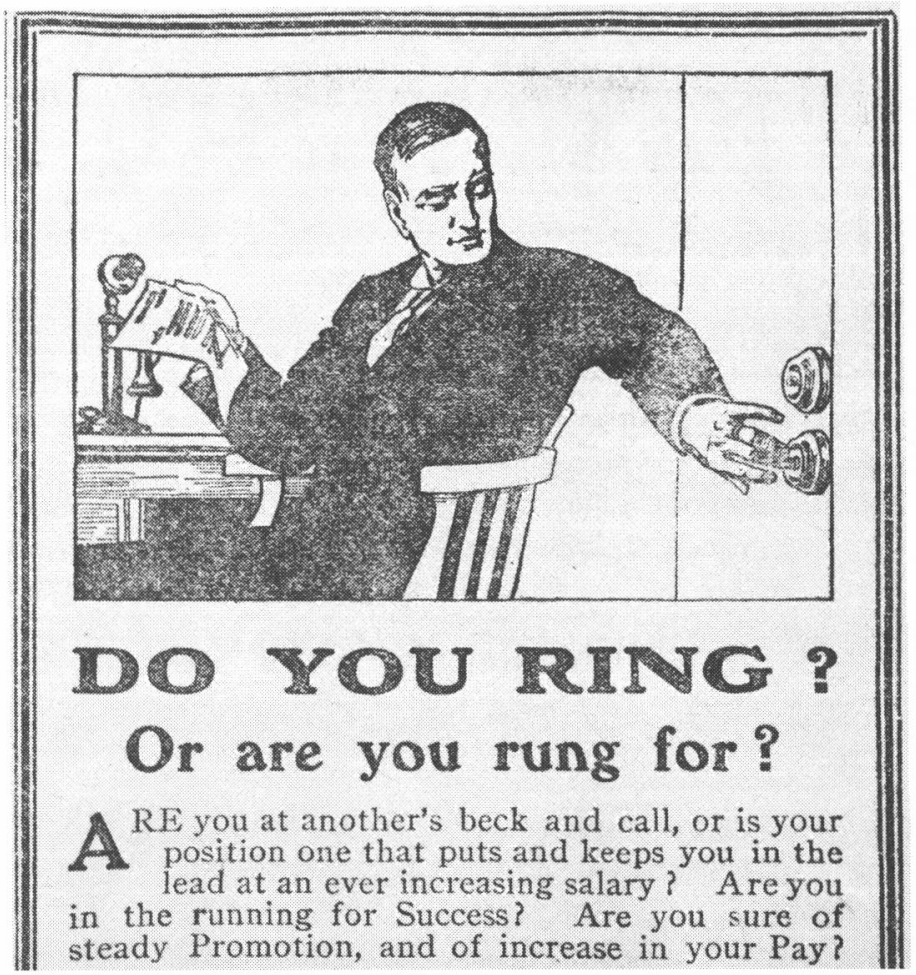

Advertisement for International Correspondence School, published in Ireland's Own in August 1914. Image courtesy of the National Library of Ireland.

forms, Ireland was at least implied in many of the British concerns about masculinity, empire and degeneration. The local context was highly specific, however. The Parnell scandal of the 1890 os had placed a particular emphasis in the Irish public imagination upon both specific and general connections between individual self-governance and national self-governance. Parnell's disgrace intertwined the private, in the form of adultery, with the public, in the form of his loss of power in the Irish Parliamentary Party and the damage that party's split did to the cause of Home Rule for Ireland. ${ }^{40}$

Importantly, as Joseph Valente has pointed out, prior to the divorce scandal Parnell's reputation for icy calm in the heat of political battle had "embodied an analogy between personal self-government, the defining virtue of achieved manliness, and collective self-government, the aim of Irish nationalism . . he 
seemed to possess something akin to a Home Rule of the soul." ${ }^{41}$ This made his fall from grace, in the aftermath of public revelations of his adultery, even more precipitous than it might otherwise have been, and underlines the sense of betrayal that many previous supporters felt about Parnell. Certainly, a connection between loss of personal self-control and a consequent loss of the opportunity for national self-determination must have existed in the popular Irish imagination of the early twentieth century.

By then there was also a strain of Irish nationalism deeply concerned with issues of Irish masculinity as it related to the concept of self-government in both personal and national terms. Reacting against a longstanding colonial model of Irish male emasculation and feminization, this model of ideal Irish manhood contrasted its "Celtic" manliness with what was presented as an effete Englishness. Many of the calls for de-Anglicization in Ireland contained some degree of contrast between "manly" Celticism and "effete" Anglicization. One of the best known examples of Irish nationalists concerned with masculinity was Padraig Pearse, who established a boys' school to train young Irish men in a specifically Irish form of masculinity, which would reclaim the precolonial heroism of such figures as Cú Chulainn and act as an antidote to the feminizing influence of the Anglicized education system in Ireland. ${ }^{42}$ The establishment of sporting, military, and quasi-military nationalist organizations - especially those for boys and young men, such as Countess Markievicz's Na Fianna Eireann, and the Gaelic Athletic Association-clearly mirrored similar movements in England such as Baden-Powell's Boy Scouts and the emphasis upon team sports within English public schools. They did so within a specifically Irish context, one in which Irish masculinity and its ability to put physical force nationalism into action were in direct and deliberate contrast to Englishness.

Studies of the generation of middle-class Catholics who came of age in the early twentieth century have suggested that they felt themselves to be, in effect, in training for Home Rule. Men (and the few women) who were able to attend university and enter the professions saw in the apparent advance of the Home Rule movement a dramatic widening of their own opportunities for the exercise of power-political, economic, and social. ${ }^{43}$ Alvin Jackson has argued of this group that "Home Rule promised these thwarted Catholics a further social and economic liberation-a removal of the glass ceiling that, under the old system,

41. Joseph Valente, The Myth of Manliness in Irish Culture, 1880-1922 (Champaign: University of Illinois Press, 2010), p. 34.

42. Elaine Sisson, Pearse's Patriots, St. Enda's and the Cult of Boyhood (Cork: Cork University Press, 2004), p. 13.

43. See Senia Pašeta, Before the Revolution: Nationalism, Social Change and Ireland's Catholic Elite, 1879-1922 (Cork: Cork University Press, 1999). 
appeared to curtail their advancement." ${ }^{44}$ The fervent attempts by many lowermiddle-class or working-class boys and girls to pass entrance examinations and become clerks or typists suggest that the aspirations of those lower down the socioeconomic scale were also being affected by the expectations of imminent Home Rule. The concept of national self-determination so central to the Home Rule crisis of 1912 appears to have had more personal resonances for that generation, too.

The Irish clerk, like his English counterpart, was a ready target for accusations of unmanliness. As with English examples of the profession, his labor, performed indoors while wearing a suit, and employed as part of a rigid hierarchy, easily allowed him to be presented as physically stunted or undeveloped, often exhibiting a pallor, stoop, or squint. A specifically Irish inflection of the denigration of clerks' manliness, however, was the implication that their acquisition of lower middle-class status was synonymous with the acquisition of Anglicized values and culture, and that in turn this Anglicization was also effeminizing. D. P. Moran's famous diatribe against Anglicization in the first issue of the Leader, published in September 1900, makes this clear. He argued that while he did not see the real "English gentleman" as an appealing figure, in England he was at least a "natural" product, despite apparently having difficulty in living on

three or four thousand a year. It is a small competence amongst his class. But when a young Irish bank clerk with $\mathfrak{E} 60$ a year is induced ... to lisp, and dawdle and entertain notions of what he foolishly considers English "gentility", we cannot see that the causes which tend to produce such effects can be said to make for honesty, nationality, progress, good conduct or any other worthy thing. ${ }^{45}$

The cause against which Moran was inveighing here was the Irish education system. It is significant that he should have chosen a bank clerk to symbolize its product; an Anglicized, "lisping," and unmanly Irishman.

Moran was not alone in presenting unsympathetic portraits of Irish clerks, however. Joyce's story "Counterparts" in Dubliners features Farrington, a legal clerk who, after a day of humiliations in both his work and social life, returns home and beats his young son. Not surprisingly, critical readings of the story have tended to focus on its graphic representation of domestic violence as the result of a frustrated, violent, and distorted masculinity, which most critics suggest Joyce is ascribing to the conditions of colonialism. ${ }^{46}$ But Joyce's decision to

44. Alvin Jackson, Home Rule: An Irish History, 1800-2000 (Oxford: Oxford University Press, 2003), p. 21.

45. D. P. Moran, “A Doomed Procession," Leader, September, 1900, pp. 7-8.

46. See David Lloyd, “Counterparts: Dubliners, Masculinity, and Temperance Nationalism," in Semicolonial Joyce, ed. Derek Attridge and Marjorie Howes (Cambridge: Cambridge University Press, 2000), pp. 128-49. 
make Farrington a clerk-along with some of his specific experiences during the course of the story-are also significant to its portrayal of a man plagued by weakness and failure. Indeed, the story's opening lines, "The bell rang furiously and, when Miss Parker went to the tube, a furious voice called out in a piercing north of Ireland accent: - Send Farrington here!" are remarkably reminiscent of the International Correspondence School's advertising slogan "Do you Ring? or are you rung for?" 47 The answer, in Farrington's case, is obviously that he was rung for. As such he was, at his age, a failure in the race for success and selfdetermination in office life.

All of his subsequent failures to perform the copying task he is working on, his secret visit to a local pub during working hours, and his later very public confrontation and humiliation for not completing his work, merely serve to emphasize that Farrington is not just a clerk —an already dubious male figure-but a failed clerk, perhaps even one of the " 30 a week men" so scathingly referred to in advertisements for the Holborn Hall College correspondence school. ${ }^{48}$ After this bruising day of professional failure, Farrington seeks solace in an evening of drinking with his fellow clerks. As the evening unfolds uneasily, they eventually find themselves in Mulligan's pub on Poolbeg Street along with a troupe of English actors from the nearby Tivoli Theatre. Farrington, vainly attempting to impress one of the women performers, becomes involved in an argument about strength with one of her colleagues. This results in an arm-wrestling contest which, in a final humiliation for the day, Farrington loses.

The day's humiliations culminate in Farrington's failure at a test of physical strength - an especially appropriate indignity, given that the entire story is threaded with references to Farrington's sense of his own strength, or lack of strength. As he struggles to copy the document he has been ordered to finish that afternoon, and becomes enraged as he realizes that he will not be able to complete it in time, we are told that, "he felt strong enough to clear out the whole office single-handed. His body ached to do something, to rush out and revel in violence" $(D$ 74). When he has his confrontation with the chief clerk, Alleyne, and in a moment of temper insults him in front of the whole office, Alleyne's fury is indicated by his shaking his fist in Farrington's face "till it seemed to vibrate like the knob of some electric machine" ( $D$ 75), suggesting again a connection between electricity and human vitality.

Farrington is forced into a humiliating apology and when he walks through the evening streets of Dublin immediately after this, he compensates for his feeling of mortification by "staring masterfully at the office girls" $(D 76)$ walking

47. James Joyce, “Counterparts." Dubliners (1914: New York: Norton Critical Edition, 2006), p. 70; hereafter cited parenthetically, thus: $(D>0)$.

48. Holborn Hall College advertisement, Ireland's Own, March 24, 1915, p. 17. 
past him. And when, after an evening's drinking he becomes involved in the arm-wrestling contest in an effort to bolster his self-esteem, the contest follows a boisterous discussion of "feats of strength," and Farrington showing off his biceps muscle to the assembled drinkers in Mulligan's back room. When he loses the arm-wrestling, "Farrington's dark winecoloured face flushed darker still with anger and humiliation at having been defeated by such a stripling" (D 80), and as he leaves the pub and waits for the tram to take him home, he was "full of smouldering anger and revengefulness. He felt humiliated and discontented" (D 80). These descriptions of Farrington's feelings of rage and shame bear a striking similarity to those alluded to in the advertisements for Ambrose Wilson's Magneto Belt, such as one from 1913 that adjured readers to "Be a Man. Be Strong, Be Vigorous, Be Courageous and Self-Reliant," and went on to claim that using the Magneto Belt would cure those who were "well-nigh crazy with depression, down-hearted, ambitionless, weak-spirited, weak-willed. ..." ${ }^{9}$

The mass media - in the form of newspapers, magazines, popular literature, and advertising-were the vehicle for many of the anxieties about weakness and degeneration. However, the mass media and its audiences were also part of the concern itself. The increasingly visible existence of these forms seemed, to some commentators, to emphasize the degeneration of national publics into undifferentiated masses. And it is surely significant that an Irish publication such as Ireland's Own relied on the advertising revenue for electric belts and self-help books on personal magnetism placed by English and even American companies. Just as the anxieties about the manliness - and personal success-of the lowermiddle-classes were international, so, too, were the mass media structures that both created and fed those anxieties.

The very nature of such story papers as Ireland's Own, which supplied a diet of adventure and romance narratives to young lower-middle-class readers, was that they were creating a structure of feeling in which individual will and selfdetermination were dominant. As such, these papers and the stories they published were examples of the broader international mass culture of the time, very similar in both format and content to equivalent stories published in British and American story papers, and alongside often identical advertisements for electric belts and self-help books. At the same time, the local contexts in which both the stories and the advertisements were consumed, and in which their mass audience was formed, must also be noted. In the midst of the Home Rule crisis of 1912, the issues of agency, self-determination, and power had a particular and an unmistakeable resonance in Ireland.

M MAYNOOTH UNIVERSITY stephanie.rains@nuim.ie

49. Magneto Belt advertisement, Ireland's Own, November 19, 1913, back wrapper. 